UDK 005.658.5 (075.8)

DOI: $10.18524 / 2413-9998 / 2020.2(45) .201437$

\author{
A. I. Yakovlev, \\ $\mathrm{PhD}$ in economics, assistant professor, \\ of the Department of Management and Innovation \\ of Economics and Management Department \\ Odessa I. I. Mechnikov National University \\ 24/26 Frantsuzkyi bulvar, Odessa, 65058, Ukraine \\ e-mail: yalexander@ukr.net
}

\title{
MANAGEMENT OF THE PRODUCTION PROCESS OF CROP PRODUCTION IN THE OPEN FIELD
}

The article formulates the main tasks of constructing a system for managing the process of crop production in the open field based on technologies and tools of operational management, managerial accounting, automation of the collection, transmission and processing of information of process parameters. Ways of solving these problems are determined. The principles of distinguishing operations during the decomposition of the crop production process are proposed.

Key words: operational management; managerial accounting; process management; automation; production process; crop production; crop production in the open field; productivity; efficiency.

Introduction. Crop production in the open field currently holds the main agricultural sector in Ukraine. In the structure of Ukraine's export, products of plant origin make up a significant share and are one of the main constituents of foreign trade. At the same time, the profitability of crop production has been declining in recent years. This is due to the increase of prices for resources used in the production process and the insufficient efficiency of their use, lower prices for crop products, low productivity due to adverse weather conditions and other reasons. Obviously, of all the factors listed above to reduce the profitability of crop production, any agricultural enterprise can affect only one - the efficiency of use of production resources. Therefore, the management of the process of crop production in the open field should increase the efficiency of use of production resources, lead to lower production costs without loss of speed and quality of execution of all process operations. 
Hypothesis for Study. The problem is in the lack of comprehensive scientific and technical developments and recommendations for constructing control systems for the process of crop production in the open field based on technologies and tools of operational management and automation capabilities for collecting, processing and transmitting information of the parameters characterizing each process operation and environmental conditions in which it is carried out.

Analysis of recent research and publications. The theory and practice of operational management are aimed at ensuring rational and effective management of operations related to the deliberate transformation of materials, information or customers [5]. Since any production activity, including the process of crop production, is a combination of interconnected and interdependent operations, in order to increase the effectiveness, efficiency, speed and quality of this process, it should be managed on the basis of technologies and tools of operational management.

A necessary condition for rational and effective management of the crop production process based on operational management technology is the "transparency" of the managed process. To ensure the "transparency" of the process, it is necessary that all operations of the process are defined and described. For each operation, parameters must be set in advance, the combination of which characterizes the state of this operation with sufficient necessity, the environmental conditions in which it is performed, and the result obtained. By comparing the normative and planned indicators of the parameters of each operation and the process as a whole with the actual values of these indicators, the progress of each operation of the process and its result is monitored, all requirements and restrictions are met during their implementation.

The purpose of this article is to formulate the main tasks for the formation of a process control system for the production of crop products in the open field based on technologies and operational management tools and determine ways to solve them.

A study of the theory and practice of operational management $[2 ; 3$; $4 ; 6]$, managerial accounting [1] and the study of modern capabilities to 
automate the measurement, processing and transmission of information characterizing the process of crop production in the open field allows us to state that the control of the technological process of crop production in the open field based on the introduction of technologies and tools for operational management, management accounting and the use of currently available information technologies that automate the collection, transmission and processing of information on the parameters and results of ongoing technological agricultural operations is a prerequisite for increasing the efficiency and effectiveness of the process of crop production in the open field. To build such a process control system, which is considered as a control object in this article, it is necessary to solve three main problems:

- to carry out modeling and operational description of the technological process of crop production in the open field for each type of product based on technology and process management tools;

- determine critical parameters and their planning and normative values characterizing the beginning and end of an operation, acceptable conditions for implementation (requirements and limitations), the state and results of each operation of the process and the process as a whole;

- identify methods and choose means for measuring, transmitting and processing all the parameters of the control object that are of interest - individual operations and the technological process of crop production as a whole.

This work is descriptive in nature and is based on the study of the process of crop production in open ground at the enterprise Agrofirm "Eurika" LTD (Ukraine, Odessa region).

Presentation of the main research material. The technological process of crop production in the open field is a stable, targeted set of interrelated technological operations that transforms the "input" - seeds, seedlings, seedlings of a particular agricultural plant into the corresponding "output" - grain, seeds, vegetables, berries, fruits that are of value to the consumer. It can be decomposed into subprocesses, up to the simplest operations, the further decomposition of which is impractical.

When describing the technological processes of crop production, it is important to correctly determine the depth of decomposition - the 
appropriate degree of detail of the process description. What criteria must an operation meet in order to make it expedient to include it as a separate element (control object) in the description of the production process? As separate operations, the components of the crop production process, I suggest the allocation of operations corresponding to the following criteria:

- the results of the operation should be significant (make a significant contribution to the final result of the production process) and measurable;

- the operation must have a clearly defined beginning and end;

- the costs of the operation must be substantial (be significantly more than the costs of their planning, accounting, control, analysis and regulation).

As a basis for describing the process of crop production, we propose using technological maps, which are a plan of agrotechnical and organizational-economic measures for the cultivation of one or a group of crops similar in technology that are found in almost every plant growing enterprise. A study of technological maps used by domestic agricultural enterprises allows us to conclude that, when describing the process of crop production for operational management purposes, the set and / or depth of detail of operations will not coincide with the set and / or level of detail of operations presented in these maps.

So, part of the agrotechnical operations contained in technological maps needs a more detailed description. For example, irrigation operations in technological maps are often not described in sufficient detail, which does not allow planning, accounting, control and analysis of these operations in accordance with the requirements of operational management.

Some critical operations (from the point of view of their influence on the final results of the process) are not contained in the technological maps at all. Such operations should include phytomonitoring. Phytomonitoring is a monitoring of the plant's life, while monitoring the environment (soil moisture, air temperature, rainfall, insect and weed populations, etc.), which makes it possible to make informed management decisions regarding managed crop factors: watering, fertilizing, chemical treatments, loosening and other agricultural operations. 
Phytomonitoring consists of the following operations: visual inspection of the field by specialists; sampling of plants, insects, soil, irrigation water; laboratory analysis of soil plants, irrigation water; collecting and processing information from instrumental phytomonitoring stations (data on temperature, light, wind, precipitation, and many other indicators). The costs directly to perform these operations are relatively small, but the efficiency and effectiveness of management decisions aimed at increasing productivity, reducing costs and improving the quality of crop production depend on the timeliness and quality of these operations.

Having determined the composition of operations of the crop production process, it is necessary to determine a set of parameters for each operation. A systematic measurement, accounting, control and analysis of these parameters should provide interested officials with the opportunity to assess the current status of each operation of the production process, the conditions in which it is carried out and the results achieved at any time.

Traditionally, companies measure and control the amount of resources consumed in the course of operations and the amount of work performed. However, the effectiveness and efficiency of the use of resources in the implementation of agricultural operations depends on the conditions in which they are carried out. For example, when treating plants with plant protection products, environmental parameters such as air temperature and wind speed are important. So, if you process plants at an air temperature above the standard, then the cost of this operation will not only not bring a positive effect, but can also lead to inhibition or even death of plants.

Therefore, along with the traditionally measured, taken into account and controlled parameters of agricultural operations, it is necessary to measure, take into account, control and analyze the parameters of the environment in which the operation is carried out and other parameters affecting the effectiveness, efficiency and quality of work, which are usually not subject to measurement, accounting, control and analysis. For example, such a parameter as the speed of movement of agricultural machinery. So, if the speed of the harvester when harvesting grain 
crops is higher than optimal, losses increase, which leads to lower yields and, accordingly, to an increase in the cost of production. If this parameter is not controlled, then the combine harvesters strive to clean as quickly as possible, since their reward is usually associated with the harvested area.

It is important to note that it is impossible to increase the effectiveness and efficiency of operational activities without automating the collection, transmission and processing of information. This is especially true for crop production in the open field.

The enterprises engaged in crop production in the open field operate on large areas - from hundreds of hectares to hundreds of thousands of hectares. Such a spatial scale of agricultural operations in the process of crop production leads to large labor and time costs for measuring the parameters of operations and transferring this information to interested parties.

Moreover, the probability that the measurement results correspond to the actual state of the measured object is not high enough. The unreliability of the measurement results of the parameters of the controlled operation obtained using traditional methods and means of measurement is a consequence of both insufficiently accurate traditional measuring instruments and distortions that appear during the measurement, fixation, transmission of information related to the «human factor». People, due to carelessness or negligence, can unintentionally or intentionally provide in the reports false results of measurements of parameters characterizing agricultural operations. In addition to the fact that the results of such measurements are highly likely to be unreliable, they, for objective reasons, are late to interested parties.

It is clear that the quality and efficiency of management decisions made on the basis of inaccurate and late information cannot be satisfactory.

The obvious way to solve this problem is to improve methods and means of measurement. Automation of the collection, transmission and processing of information on the parameters of technological agricultural operations allows us to achieve the necessary level of effi- 
ciency, continuity and reliability of information support for managers who manage the processes of crop production.

The collection, processing and transmission of information about a controlled operation without human intervention implies direct continuous automatic measurement, recording, monitoring and analysis of the parameters of the controlled operation and the environment and automatic notification in real time of interested parties about the deviation of the actual parameter values from the standard.

To automate the collection, processing and transmission of information on agricultural operations, it is necessary to carry out electronic mapping of the fields, install the appropriate equipment on agricultural machinery and implements, and keep up to date the normative values of all predetermined parameters of operations and the environment for each crop.

For example, if the sprayer at a certain point in time is outside the boundaries of the field on which the plants should be treated with crop protection systems at this time, this deviation is automatically recorded and information about this is automatically transmitted to smartphones of predefined stakeholders. The normative / planned parameters of the operation, in this case time, the coordinates of the field boundaries using the appropriate program are compared with the actual coordinates of the location of the corresponding equipment and tools. In case of deviations, this information is recorded and automatically sent to predetermined persons in the form of a notice.

Also, when performing a plant treatment operation with protective equipment, if one of the parameters, for example, air temperature or wind speed or the speed of the sprayer is outside the permissible limits of the pre-set values of these parameters, information about this is recorded and sent to smartphones in advance in the form of an appropriate notification to certain individuals. Based on this information, these persons have the opportunity to take measures to bring the operation in line with the specified parameters, or to stop the operation if it is impossible to influence certain parameters (for example, air temperature).

At present, it is possible to automatically measure, take into account, control, analyze and distribute many parameters characterizing 
agricultural operations and the environment in which they are carried out. Including information on fuel consumption, expenditure of working time, speed, driving directions and downtime, the treated area and the coordinates of this area, etc.

When performing control operations, for example, operations to control the quality of plowing, the agronomist must measure the soil density along a predetermined route with a predetermined frequency to control the depth of plowing.

At present, the agronomist can be provided with devices, with the help of which information on time, route of movement, coordinates of points at which density measurements were made and the results of measurements of soil density are automatically detected, recorded and transmitted. This information with the help of the appropriate program is compared with regulatory data and in case of deviations according to any of the parameters, the corresponding notification is automatically transmitted to predetermined persons in real time. This approach does not allow the agronomist to provide a report on the quality of plowing without taking appropriate measurements in accordance with a predetermined methodology, which is often the case at present.

The cost of equipment for measuring and transmitting parameters of agricultural operations, information transfer traffic, software products for information processing has significantly decreased in recent years and is becoming available for most agricultural organizations.

Conclusion. Thus, we can conclude that at present there are all the prerequisites for the transition to the management of the process of crop production in the open field based on operational management. To do this, you must:

- describe this process in accordance with the requirements listed above;

- determine a set of parameters characterizing each operation of the crop production process, subject to mandatory monitoring; set planning and regulatory values for each parameter;

- identify methods and choose measuring instruments, transmitting information about the results of measurements;

- choose programs for automatic data processing.

The solution of these problems will lead to an increase in the controllability of the crop production process in the open field, which 
will contribute to increasing the efficiency and effectiveness of the use of production resources.

\title{
References
}

1. Drury, C. (2008). Management and Cost Accounting. South-Western.

2. Bowman, E. \& Fetter, R. (1967). Analysis for production and operations management. Homewood, Ill. : R. D. Irwin.

3. Krajewsky, L. J. \& Ritzman, L. P. (1987).Operations management. Addison-Wesley Publishing Company.

4. 5 P's of Production Management. Retrieved from: http://www.yourarticlelibrary. com/production-management/5-ps-of-production-management-explained/57397/

5. Galloway. L. (1998). Principles of Operations Management. International Thomson Business Press.

6. McKinsey \& Company. Retrieved from : http://www.mckinsey.com/global-locations/europe-and-middleeast/russia/ru/our-work/operations

7. Schroeder, R. G. (1989). Operations management. Decision making in the operations function. McGrow-Hill.

Стаття надійшла 23.02.2020 p.

\author{
А. И. Яковлев, \\ кандидат экономических наук, доцент, \\ доцент кафедры менеджмента и инноваций \\ Одесский национальный университет имени И. И. Мечникова, \\ Французский бульвар, 24/26, г. Одесса, 65058, Украина, \\ e-mail: yalexander@ukr.net
}

\section{УПРАВЛЕНИЕ ПРОЦЕССОМ ПРОИЗВОДСТВА ПРОДУКЦИИ РАСТЕНИЕВОДСТВА В ОТКРЫТОМ ГРУНТЕ}

В статье сформулированы основные задачи построения системы управления процессом производства продукции растениеводства в открытом грунте на основе технологий и инструментария операционного менеджмента, управленческого учета, автоматизации сбора, передачи и обработки информации о параметрах процесса. Определены пути решения этих задач. Предложены принципы выделения операций при декомпозиции процесса производства продукции растениеводства.

Ключевые слова: операционный менеджмент; управленческий учет; процессный менеджмент; автоматизация; процесс производства; продукция растениеводства; растениеводство в открытом грунте; результативность; эффективность. 


\author{
О. І. Яковлєв, \\ кандидат економічних наук, доцент, \\ доцент кафедри менеджменту та інновацій \\ Одеський національний університет імені I. I. Мечникова, \\ Французький бульвар, 24/26, м. Одеса, 65058, Україна, \\ e-mail: yalexander@ukr.net
}

\title{
УПРАВЛІННЯ ПРОЦЕСОМ ВИРОБНИЦТВА ПРОДУКЦЇ̈ РОСЛИННИЦТВА В ВІДКРИТОМУ ГРУНТІ
}

У статті сформульовані основні завдання побудови системи управління процесом виробництва продукції рослинництва у відкритому грунті на основі технологій і інструментарію операційного менеджменту, управлінського обліку, автоматизації збору, передачі та обробки інформації про параметри процесу. Визначено шляхи вирішення цих завдань. Запропоновано принципи виділення операцій при декомпозиції процесу виробництва продукції рослинництва.

Ключові слова: операційний менеджмент; управлінський облік; процесний менеджмент; автоматизація; процес виробництва; продукція рослинництва; рослинництво в відкритому грунті; результативність; ефективність. 